\title{
LATIHAN FISIK DAN ASAM LAKTAT
}

\author{
Oleh: Widiyanto
}

Dosen Jurusan Pendidikan Kesehatan dan Rekreasi FIK UNY

\section{Abstrak}

Energi pada waktu latihan dipenuhi melalui dua jalur, yaitu aerobik dan anaerobik. Penggunaan system energi ini akan sangat tergantung pada intensitas latihan. Pada latihan fisik intensitas tinggi otot berkontraksi dalam keadaan anaerobik, sehinga penyediaan ATP terjadi melalui proses glikolisis anaerobik, hal ini mengakibatkan meningkatnya kadar laktat dalam darah maupun otot.

Laktat merupakan produk akhir dari metabolisme anaerobik, proses ini berlangsung tanpa adanya oksigen. Selama latihan fisik akan terjadi kenaikan kadar laktat dalam darah maupun otot. Penimbunan laktat dalam darah menjadi masalah mendasar dalam kinerja fisik, karena menimbulkan kelelahan yang kronis dan menurunkan kinerja fisik. Penggusuran laktat yang lambat menyebabkan sindroma latihan yang berlebihan pada atlet sehingga dapat mengakibatkan peningkatan insiden cedera olahraga yang dapat menyebabkan kecacatan baik sementara maupun menetap.

Kata Kunci: Laktat, latihan

Latihan yang bersemangat sampai kelelahan, berhubungan erat dengan perubahan yang besar dan cepat pada produksi energi. Perubahan cepat metabolisme penyediaan energi tersebut diperankan oleh sistem penyediaan energi anaerobik (ATP-PC dan asam laktat) dan sistem penyediaan energi 
aerobik yang lebih mengandalkan sumber energi dari lemak. Namun demikian, sampai saat ini masih belum diketahui besar perubahan yang terjadi dalam bentuk respons penurunan kadar asam laktat setelah latihan endurance dengan intensitas anaerobik tinggi yang berpedoman pada titik defleksi Conconi (Janssen, 1989: 26).

Penimbunan laktat dalam darah menjadi masalah mendasar dalam kinerja fisik karena menimbulkan kelelahan yang kronis dan menurunkan kinerja fisik (Ahmaidi, 1996: 450). Penggusuran laktat yang lambat menyebabkan sindroma latihan yang berlebihan (overtraining syndrome) pada atlet, sehingga mengakibatkan peningkatan insiden cedera yang dapat menyebabkan kecacatan baik sementara maupun menetap. Bentuk aktivitas yang dapat mempercepat pemulihan laktat adalah meningkatkan proses oksidasi dan glukoneogenesis, banyak melibatkan serabut otot merah dan mempercepat distribusi laktat dari otot aktif ke otot yang kurang aktif (Falks, 1995: 7).

Mekanisme pemulihan laktat dari darah dan otot sangat dipengaruhi oleh aktivitas yang dilakukan setelah aktivitas maksimalnya. Hal ini akan mempengaruhi mekanisme keluarnya laktat dari otot ke darah, meningkatnya aliran darah, ambilan laktat oleh hati, jantung, dan otot rangka (Weltman, 1998: 11114). Kecepatan pengeluaran laktat akan mempengaruhi proses metabolisme berikutnya, sehingga laktat dapat segera dimetabolisme kembali membentuk energi melalui siklus krebs. Menurut Falks (1995: 10) pemulihan laktat yang penting adalah meningkatkan aliran

MEDIKORA Vol.III, No 1, April 2007:61-79 
darah, meningkatkan cardiac output, meningkatkan transport laktat, sehingga cepat membentuk energi kembali.

\section{LATIHAN}

Latihan adalah suatu proses atau periode waktu yang berlangsung selama beberapa tahun sampai olahragawan mencapai standar penampilan yang tinggi (Nossek, 1982 :10). Menurut Harsono (1996: 17) latihan adalah suatu proses berlatih secara sistematis yang dilakukan secara berulang-ulang dengan beban latihan yang kian bertambah. Hal senada juga dikemukakan oleh Mosston (1992: 9) latihan merupakan pelaksanaan gerakan secara berurutan dan berulang-ulang. Pada prinsipnya latihan adalah memberikan tekanan fisik secara teratur, sistematik, berkesinambungan sedemikian rupa, sehingga dapat meningkatkan kemampuan fisik di dalam melakukan aktivitas (Fox et all., 1993: 69). Pendapat lain menyatakan bahwa latihan adalah proses sistematis dari kerja fisik yang dilakukan secara berulangulang dengan menambah jumlah beban pekerjanya. Latihan fisik merupakan pemberian kerja atau beban fisik pada tubuh secara teratur, sistematis, dan berkesinambungan melalui program latihan yang tepat (Astrand dan Rodahl, 1986: 11).

Latihan fisik sebaiknya dilakukan sesuai dengan kemampuan tubuh dalam menanggapi stress yang diberikan, bila tubuh diberi beban latihan yang terlalu ringan, maka tidak akan terjadi proses adaptasi (Sugiharto, 2003: 4). Demikian juga, jika diberikan beban latihan yang terlalu berat dan tubuh tidak mampu mentolelir akan menyebabkan terganggunya proses 
homeostatis pada sistem tubuh dan dapat mengakibatkan kerusakan pada jaringan. Setiap latihan fisik akan menimbulkan respon atau tanggapan dari organ-organ tubuh terhadap dosis atau beban latihan yang diberikan, hal ini merupakan usaha penyesuaian diri dalam rangka menjaga keseimbangan lingkungan yang stabil atau bisa disebut juga dengan homeostatis (Sugiharto, 2003: 7).

Latihan merupakan salah satu stressor fisik yang dapat menggangggu keseimbangan homeostatis. Oleh sebab itu, pemanfaatan latihan yang dikemas dalam bentuk latihan fisik memerlukan pengukuran dosis yang tepat, sehingga memberikan peluang untuk membentuk mekanisme penyakit (coping) yang mampu mengubah stressor menjadi stimulator. Tetapi bila dosis latihan yang diberikan tidak tepat, maka stressor tersebut akan mengganggu keseimbangan (homeostatis) dalam tubuh dan dapat menyebabkan masalah kelainan biologis atau patologis (Sugiharto, 2003: 1).

Semua aktivitas fisik merupakan stressor bagi tubuh. Jika tubuh diberi stressor yang dilakukan secara teratur, berkesinambungan dan disertai dengan program latihan yang tepat, maka tubuh akan beradaptasi dengan membentuk mekanisme coping yang mampu mengubah stressor menjadi stimulator. Pemberian beban latihan akan ditanggapi oleh tubuh dalam bentuk respon, jika dosis yang diberikan tepat akan menghasilkan proses adaptasi yang baik. Program atau dosis latihan yang tepat harus memperhatikan beberapa unsur latihan, yaitu: frekuensi, intensitas, durasi, dan set latihan.

MEDIKORA Vol.III, No 1, April 2007:61-79 


\section{SUMBER ENERGI SAAT LATIHAN}

Energi adalah syarat penting untuk aktivitas fisik selama berlatih atau bertanding. Energi berasal dari makanan yang kita makan sehari-hari, tujuan makan selain untuk menghilangkan rasa lapar adalah untuk pertumbuhan dan menganti sel-sel yang rusak. Namun demikian sebenarnya semua energi itu berasal dari matahari, dimana energi matahari tersebut diubah oleh tumbuh-tumbuhan hijau menjadi energi kimia (Soekarman, 1987: 7). Menurut Pate (1984: 235) energi adalah daya untuk melakukan kerja. Energi umumnya diukur dengan satuan panas yaitu kilokalori (kkal). Satu kkal adalah banyaknya panas yang dibutuhkan untuk menaikkan temperatur 1 liter air $1^{0}$ Celcius.

Dalam melakukan aktivitas sehari-hari, apapun bentuknya tubuh pasti memerlukan energi. Energi adalah kemampuan untuk melakukan kerja. Berdasarkan sistem energi predominan, maka latihan dibagi menjadi dua bentuk, yaitu latihan anaerobik dan latihan aerobik. Latihan anaerobik adalah latihan yang menggunakan energi dengan sistem ATP-TC (phosphgen system) dan glikolisis anaerobik (lactic acid system), dan latihan aerobik adalah latihan yang menggunakan sistem energi glikolisis aerobik (aerobic glicolysis). 
Pada latihan fisik energi yang diperlukan akan bertambah, karena disamping untuk mempertahankan fungsi-fungsi tubuh diperlukan tambahan energi untuk latihan itu sendiri. Penambahan energi tersebut dapat dilaksanakăn dengan menggunakan sistem energi aerobik dan anaerobik. Bila digunakan sistem energi aerobik, maka diperlukan penambahan pasokan $\mathrm{O}_{2}$, namun penambahan pasokan $\mathrm{O}_{2}$ ini akan memerlukan waktu, karena memerlukan adaptasi sistem respiratori dan sistem kardiovaskuler. Bila latihan tersebut terjadi dengan intensitas tinggi dan dalam jangka waktu pendek, maka peningkatan pasokan $\mathrm{O}_{2}$ belum terpenuhi, sehingga terpaksa digunakan sistem energi anaerobik.

Semua aktivitas fisik memerlukan energi, jumlah kebutuhan energi tergantung pada berat dan ringannnya latihan yang dikerjakan. Latihan yang berat dan lama pengadaan energinya diperoleh dari beberapa sumber energi di dalam sel, antara lain dari long term energy system. Latihan yang dilakukan dengan frekuensi yang teratur merupakan aktivitas fisik yang menggunakan long term energy system. Pada latihan yang menggunakan long term energy system dan dilakukan secara berkesinambungan akan menyebabkan terjadinya adaptasi pada mitokondria, sehingga metabolisme energi menjadi lebih baik.

Seperti yang telah diuraikan di atas bahwa pengadaan energi di dalam sel dapat berlangsung melalui fenomena sebagai berikut, yaitu:

a. Energi yang siap pakai dan proses pengubahan keratin fosfat menjadi ATP melalui proses fosfrilasi ADP oleh kreatin fosfat dengan bantuan

MEDIKORA Vol.III, No 1, April 2007:61-79 
enzim keratin kinase. Prosesnya berlangsung sangat cepat melalui reaksi enzimatik dan terjadi saat persiapan kerja akan dimulai.

b. Energi yang diperoleh dari proses glikolisis, yaitu pemecahan glukosa atau glikogen. Fenomena pengadaan energi ini dikenal sebagai short term energy system.

c. Energi yang diperoleh dari proses fosforilasi oksidasi. Prosesnya berlangsung di dalam mitokondria. Sumber materi yang diproses berasal dari glukosa darah melalui glikolisis terlebih dahulu, asam lemak, dan asam amino. Prosesnya memerlukan banyak oksigen untuk membakar asam laktat, asam lemak, dan kalau mungkin juga asam amino yang berasal dari protein. Fenomena ini dikenal sebagai long term energy sistem. Pada fase selanjutnya pengadaan energi dan pembakaran asam lemak lebih banyak, sedangkan proses glikolisis meningkat bersamaan dengan meningkatnya jumlah enzim untuk proses glikolisis (Mas'ud, 2000: 81).

\section{SISTEM ATP-PC}

Aktivitas yang dilakukan berulang-ulang akan menyebabkan persediaan ATP di dalam otot menjadi berkurang. ATP adalah simpanan energi di dalam otot yang siap digunakan untuk aktivitas fisik. Namun, simpanan ATP ini tidak bertahan lama, karena jumlah ATP yang tersedia di dalam otot sangat terbatas. ATP yang tersedia di dalam otot hanya dapat melakukan aktivitas maksimal selama 20-30 detik saja. Oleh sebab itu, sistem ini hanya berguna untuk aktivitas fisik yang sangat cepat dan dalam 
waktu yang singkat, seperti: melompat, meloncat, memukul bola, dan lain sebagainya.

Apabila ATP di dalam otot berkurang selama melakukan aktivitas, maka perlu adanya resintesa ATP kembali untuk aktivitas berikutnya. Sistem penyediaan energi pertama yang digunakan untuk meresintesis ATP yang telah digunakan untuk aktivitas adalah sistem ATP-PC. Sistem ATPPC adalah bentuk penyediaan energi yang paling cepat dibandingkan dengan sistem penyediaan energi lain. Namun sistem ATP-PC ini tidak bertahan lama, karena jumlah PC (phosphokreatin/creatine phosphate) yang tersedia di dalam otot sangat terbatas, yaitu kira-kira 4 kali banyaknya ATP di dalam otot.

Phosphokreatin dan ATP sama-sama disimpan di dalam sel otot. Karena ATP dan PC terdiri atas kelompok fosfat, maka mereka secara bersama-sama disebut sebagai sistem fosfagen. Kesamaan antara ATP dan PC adalah kelompok fosfat ini pecah, maka sejumlah besar energi dikeluarkan. Hasil akhir dari pemecahan PC ini adalah keratin $(\mathrm{C}=$ creatin) dan fosfat inorganic $\left(\mathrm{P}_{\mathrm{i}}\right)$. Energi ini dipergunakan untuk resintesis ATP. ATP dipecah pada saat kontraksi otot berlangsung, kemudian dibentuk kembali dari $\mathrm{ADP}+\mathrm{P}_{\mathrm{i}}$ oleh adanya energi yang berasal dari pemecahan simpanan PC. (Junusul Hairy, 1989 : 75).

Fosfat kreatin adalah suatu zat seperti ATP berisi fosfat energi tinggi. Tidak seperti ATP, fosfat kreatin tidak dapat digunakan secara langsung untuk menggerakkan kontraksi otot, tetapi fosfat kreatin digunakan untuk memperbaharui ATP, seperti dalam gambar di bawah ini.

MEDIKORA Vol.III, No 1, April 2007:61-79 


\section{Creatine Kinase \\ $\mathrm{CP} \longrightarrow \mathrm{C}+\mathrm{Pi}+$ energi ( 13000 kalori $)$}

Energi dan gugusan fosfat digunakan kembali untuk membentuk ATP dari ADP

$$
\text { ADP }+ \text { Pi + energi ( } 12000 \text { kalori }) \longrightarrow \text { ATP }
$$

Gambar 1. Fosfat Kreatin (FK). (Pate, Rusell R. 1984 : 238).

\section{SISTEM ASAM LAKTAT}

Sistem anaerobik selain dari resintensis ATP di dalam otot, adalah glikolisis anaerobik, yang melibatkan pemecahan tidak sempurna dari salah satu bahan makanan yaitu karbohidrat (gula), menjadi asam laktat (karena itu dinamakan asam laktat). Di dalam tubuh, semua karbohidrat dikonversi menjadi gula sederhana yaitu glukosa, yang segera dapat dipergunakan dalam bentuk glukosa, disimpan di dalam hati dan otot sebagai glikogen untuk dipergunakan kemudian. Asam laktat adalah hasil dari glikolisis anaerobik (Junusul Hairy, 1989 : 77). 
Sistem glikolisis anaerobik atau sistem asam laktat ini lebih rumit dibandingkan dengan sistem ATP-PC. Proses pembentukan energi melalui sistem asam laktat dan memerlukan 12 macam reaksi kimia yang berurutan, sehingga pembentukan energi berjalan lebih lambat jika dibandingkan dengan sistem ATP-PC. Sistem asam laktat mengubah glukosa atau glikogen pada sitoplasma sel otot menjadi energi dan asam laktat.

Proses glikolisis anaerobik memerlukan 12 macam reaksi kimia secara berurutan, sehingga energi yang terbentuk melalui sistem energi ini berlangsung lebih lambat dibandingkan dengan sistem ATP-PC yang hanya membutuhkan 2 reaksi kimia saja. Jadi, untuk kontraksi otot yang sangat cepat digunakan ATP-PC, sedangkan untuk kontraksi otot yang cepat digunakan sistem anaerobik. Proses ini berlangsung tanpa adanya oksigen, sehingga asam laktat merupakan produk akhir dari metabolisme glukosa dengan sistem metabolisme anaerobik. Ciri-ciri dari sistem glikolisis anaerobik adalah sebagai berikut: (1) menyebabkan terbentuknya asam laktat yang dapat menyebabkan kelelahan, (2) tidak membutuhkan oksigen, (3) hanya menggunakan sumber energi karbohidrat (glikogen dan glukosa), dan (4) energi yang dilepaskan hanya cukup untuk resintesis $\Lambda T P$ dalam jumlah yang sedikit.

Seperti telah dijelaskan di atas bahwa produk akhir dari glikolisis anaerobik adalah asam laktat. Asam laktat akan menurunkan $\mathrm{pH}$ dalam otot maupun darah. Selanjutnya, penurunan $\mathrm{pH}$ ini akan menghambat kerja enzim-enzim glikolitik dan mengganggu reaksi kimia di dalam sel otot.

MEDIKORA Vol.III, No 1, April 2007:61-79 
Keadaan ini akan mengakibatkan kontraksi otot bertambah lemah dan akhirnya otot mengalami kelelahan.

Dalam kegiatan berolahraga atlet seringkali diminta untuk terus menerus berlatih dengan sungguh-sungguh dalam waktu yang cukup lama. Dalam keadaan demikian, energi yang dipakai berasal dari karbohidrat yang tersimpan, yakni glikogen sebagai bahan pokoknya. Glikolisis anaerobik meliputi satu rangkaian reaksi kimia yang melepaskan energi dari molekul glikogen. Energi ini digunakan untuk memperbaharui ATP, yang sebaliknya digunakan dalam kontraksi otot.

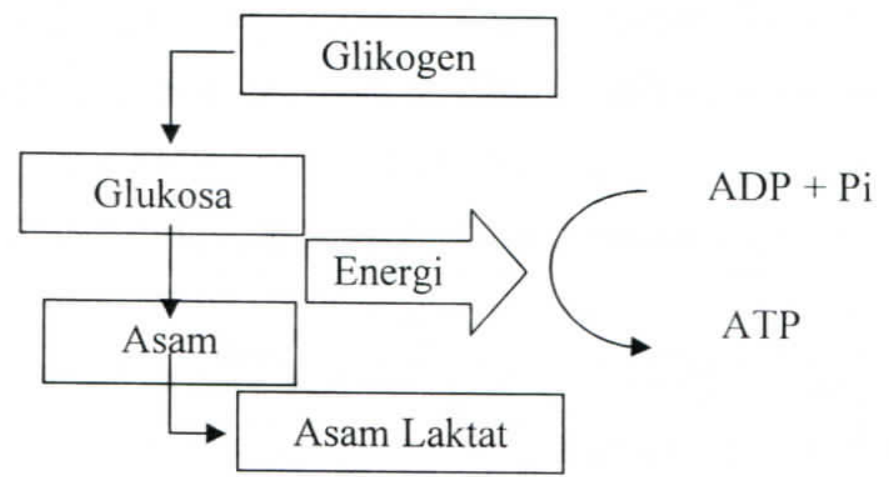

Gambar 2. Glikolisi anaerobik. (Pate, Rusell R.,1984 : 238).

Meskipun asam laktat merugikan, tapi asam laktat merupakan sumber energi untuk metabolisme anaerobik. Pada saat jumlah oksigen mencukupi, maka asam laktat akan dioksidasi untuk menghasilkan energi melalui metabolisme aerobik. Asam laktat diubah kembali menjadi asam piruvat. Asam piruvat ini masuk ke dalam mitokondria untuk mengalami suatu rangkaian proses oksidasi Siklus Kreb dan Sistem Transportasi 
Elekton untuk menghasilkan energi (untuk resintesa $\mathrm{ADP}+\mathrm{Pi}$ ), $\mathrm{H}_{2} \mathrm{O}$, dan $\mathrm{CO}_{2}$.

\section{LAKTAT DAN LATIHAN}

Laktat merupakan intermediate product dari metabolisme glukosa. Laktat merupakan produk akhir dari metabolisme anaerobik, proses ini berlangsung tanpa adanya oksigen. Kadar laktat darah orang sehat dalam keadaan istirahat sekitar 1-2 mM/L (Jenssen, 1989: 14). Pada latihan fisik intensitas tinggi otot berkontraksi dalam keadaan anaerobik, sehingga penyediaan ATP terjadi melalui proses glikolisis anaerobik. Hal ini mengakibatkan peningkatan kadar laktat dalam darah maupun otot.

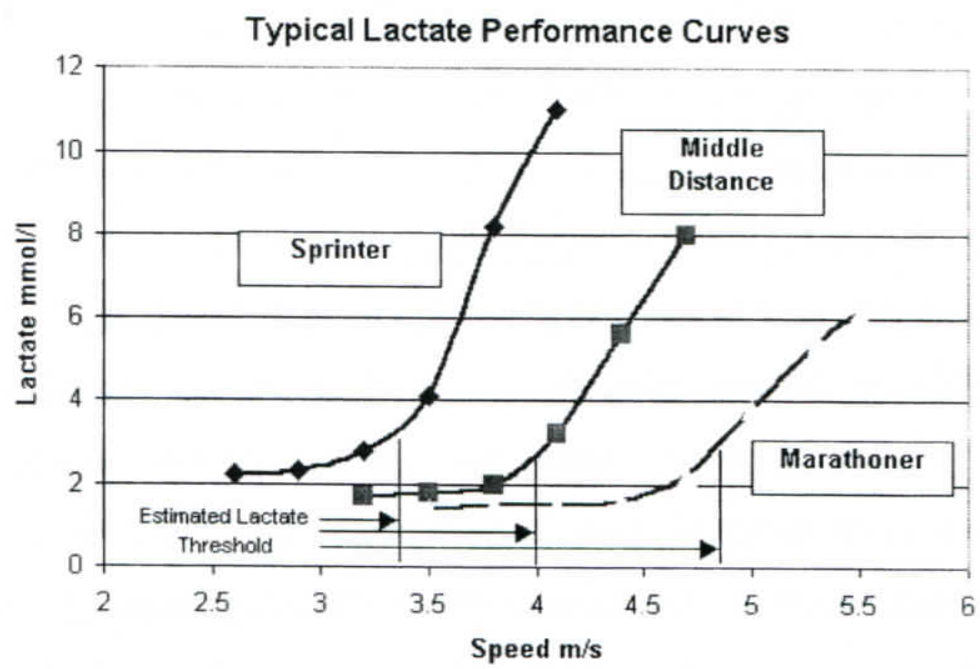

Gambar 3.

Tipe curve laktat dan penampilan (http://www.lactate.com/pitesbas.html)

MEDIKORA Vol.III, No 1, April 2007:61-79 
Pada latihan fisik dengan intensitas tinggi otot berkontraksi dalam keadaan anaerobik, sehingga penyediaan ATP terjadi melalui proses glikolisis anaerobik. Hal ini mengakibatkan meningkatnya kadar laktat dalam darah maupun otot. Tetapi otot yang terlatih tetap dapat berkontraksi dengan baik pada konsentrasi asam laktat yang cukup tinggi. Segera setelah mendapat oksigen, asam laktat diubah kembali menjadi asam piruvat dan selanjutnya diubah menjadi energi, karbondioksida dan air. Jadi, asam laktat merupakan sumber energi yang dapat digunakan sebagai piruvat, piruvat masuk ke dalam Siklus Kreb's dan Sistem Transport Elektron sehingga menghasilkan energi, $\mathrm{H}_{2} \mathrm{O}$, dan $\mathrm{CO}_{2}$ (Soekarman, 1987: 10).

Konsentrasi maksimal asam laktat pada darah dan otot manusia setelah latihan belum diketahui secara pasti, tetapi diperkirakan mencapai di atas $20 \mathrm{mM} / \mathrm{l}$ darah dan $25 \mathrm{mM} . \mathrm{Kg}-1 /$ berat otot basah. Asam laktat yang terbentuk pada saat latihan fisik berat akan masuk ke dalam darah. dan banyaknya laktat yang masuk sebanding dengan tingginya kadar laktat dalam otot.

Penyingkiran asam laktat darah akan berlangsung lebih cepat apabila proses pemulihan dilakukan dengan istirahat aktif, yaitu melakukan aktivitas ringan atau sedang. Penyingkiran asam laktat pada individu yang tidak terlatih akan lebih optimal apabila dilakukan dengan aktivitas fisik pada intensitas antara 30-45 \% $\mathrm{VO}_{2}$ maks, sedangkan bagi atlet atau individual dilakukan dengan aktivitas fisik pada intensitas antara 50-65\% $\mathrm{VO}_{2}$ maks. 
Ciri adanya penimbunan asam laktat (acidosis) adalah rasa sakit pada tungkai (untuk pembalap sepeda atau pelari) atau rasa sakit pada lengan (untuk dayung). Hal ini menyebabkan rasa tidak berdaya.

\section{EFEK PENUMPUKAN ASAM LAKTAT}

Latihan anaerobik yang berlangsung secara glikolisis anaerobik akan meningkatkan konsentrasi asam laktat dalam sel otot. Peningkatan konsentrasi asam laktat tersebut akan menurunkan $\mathrm{pH}$ dari sel (tingkat keasaman dalam sel lebih tinggi dibandingkan di luar sel). Enzim-enzim di dalam sel sangat peka terhadap $\mathrm{pH}$. Penurunan $\mathrm{pH}$ menyebabkan penurunan kecepatan reaksi dari enzim-enzim di dalam sel, sehingga menurunkan kemampuan metabolisme dan produksi ATP.

Keberadaan asam di dalam otot akan mengganggu berbagai mekanisme sel otot, yaitu: (1) mengahambat enzim aerobik dan anaerobik, sehingga menurunkan kapasitas ketahanan aerobik (endurance aerobic capacity) dan kapasitas ketahanan anaerobik (endurance anaerobic capacity), (2) menghambat terbentuknya creatin phospat (CP) dan akan mengganggu koordinasi gerak, (3) menghambat enzim fosfofruktokinase, (4) menghambat pelepasan ion $\mathrm{Ca}^{++}$pada troponin $\mathrm{C}$ mengalami penurunan, dan mengakibatkan gangguan atau terhentinya kontraksi serabut otot. (5) menghambat aktivitas mATPase terutama pada serabut otot cepat, karena mATPase pada serabut otot cepat peka terhadap asam.

Dosis yang tepat dan latihan yang teratur akan memberikan perubahan peningkatan kemampuan secara maksimal, sehingga 
menghasilkan kinerja secara maksimal pula. Aktivitas fisik yang dilakukan secara teratur akan memberikan penyesuaian terhadap tubuh, sehingga akan mengurangi gangguan terhadap milieu interiuer sel, meminimalkan kelelahan, meningkatkan kinerja, dan mengurangi penggunaan tenaga secara berlebihan selama aktivitas.

Otot dapat melakukan aktivitas yang sangat kuat selama beberapa detik dengan membutuhkan energi ekstra. Sebagian besar energi ekstra tersebut dibutuhkan selama kerja berat dalam waktu lebih dari 5 sampai 10 detik, tetapi kurang dari 1 sampai 2 menit didapatkan dari glikolisis anaerob. Akibatnya glikogen otot selama kerja berat menjadi berkurang, sedangkan kadar asam laktat darah meningkat.

Asam laktat yang tinggi dapat timbul sebagai akibat beban kerja yang berat, hal ini karena ketidakmampuan sitem pemasok energi aerobik, sehingga suplai energi dari sumber anaerobik mendominasi (Janssen. 1989: 13). Namun demikian dalam keadaan istirahat laktat tetap terbentuk, hal ini karena adanya reaksi reduksi asam piruvat oleh NADH dengan pertolongan laktat dehidrogenase (LDH) yang tetap berlangsung walaupun dalam jumlah yang sedikit. (Mattner, 1988: 11). Reaksi ini terjadi karena adanya sebagian sel-sel tubuh yang tidak megandung mitokondria, misalnya: eritrosit dan bagian tubuh yang hanya mengandung sedikit mitokondria, misalnya: sel otot fast twitch.

Latihan dengan intensitas lebih dari $50 \% \quad \mathrm{VO}_{2}$ maks akan meningkatkan penumpukan asam laktat, sehingga dapat menurunkan $\mathrm{pH}$. Pada latihan sub maksimal diperkirakan terjadi penumpukan $\mathrm{H}^{+}$yang 
berpengaruh terhadap perubahan $\mathrm{pH}$. Dalam keadaan istirahat tubuh memiliki pH darah normal 7,4 dan pada latihan fisik $\mathrm{pH}$ dapat menurun menjadi 7,0 dan pada latihan fisik yang maksimal $\mathrm{pH}$ darah dapat turun hingga 6,5. Penurunan $\mathrm{pH}$ darah dan otot dapat menyebabkan produksi asam laktat pada jaringan hypoxia dan menurunkan penggusuran asam laktat oleh hati karena terhambatnya glikolisis (Bangsbo, 1997: 489).

Penimbunan laktat dalam darah menjadi masalah mendasar dalam kinerja fisik, karena menimbulkan kelelahan yang kronis dan menurunkan kinerja fisik (Ahmaidi, 1996: 450). Penggusuran laktat yang lambat menyebabkan sindroma latihan yang berlebihan (overtraining syndrome) pada atlet, sehingga mengakibatkan peningkatan insiden cedera yang dapat menyebabkan kecacatan baik sementara maupun menetap. Bentuk aktivitas yang dapat mempercepat pemulihan laktat adalah meningkatkan proses oksidasi dan glukoneogenesis, banyak melibatkan serabut otot merah dan mempercepat distribusi laktat dari otot aktif ke otot yang kurang aktif (Falks, 1995: 7).

Sejumlah besar asam laktat yang diproduksi oleh otot selama latihan dirubah menjadi asam piruvat kemudian dipecah menjadi karbon dioksida dan air di dalam mitokondria. Bagaimanapun juga, asam laktat dapat berdifusi keluar dari otot dan masuk ke dalam darah, diambil kembali, dan digradasi untuk energi oleh otot yang lain. Cara lain tentang penggunaan asam laktat sebagai energi adalah: asam laktat dikeluarkan olch darah ke hati, di hati asam laktat dirubah menjadi glikogen hati, melalui glikolisis. Glikogen hati kemudian dipecah menjadi glukosa yang masuk ke dalam

MEDIKORA Vol.III, No 1, April 2007:61-79 
darah dan diangkut kembali ke otot untuk dipergunakan di dalam glikolisis atau disimpan sebagai glikogen. Daur dari otot ke hati dan kembali lagi ke otot, dinamakan Daur Cori. Daur Cori terutama berguna selama latihan yang lama dan pulih asal, karena keduanya membantu untuk mengangkut asam laktat, sebagai zat yang mempercepat kelelahan. Daur Cori mengisi glukosa darah untuk kontinuitas suplai energi ke otot, sehingga latihan dapat diteruskan. (Junusul Hairy, $1989: 84$ ).

\section{KESIMPULAN}

Latihan secara umum dapat meningkatkan kadar asam laktat darah. Konsentrasi asam laktat yang tinggi dapat menimbulkan dampak yang merugikan bagi tubuh. Kadar asam laktat darah yang melebihi $6 \mathrm{mMol} / 1$ dapat mengganggu mekanisme kerja sel otot sampai pada tigkat koordinasi gerakan. Peningkatan konsentrasi asam laktat tersebut akan menurunkan $\mathrm{pH}$ dari sel (tingkat keasaman dalam sel lebih tinggi dibandingkan di luar sel). Enzim-enzim di dalam sel sangat peka terhadap $\mathrm{pH}$. Penurunan $\mathrm{pH}$ menyebabkan penurunan kecepatan reaksi dari enzim-enzim di dalam sel, sehingga menurunkan kemampuan metabolisme dan produksi ATP.

Meskipun asam laktat merugikan, tapi asam laktat merupakan sumber energi untuk metabolisme anaerobik. Pada saat jumlah oksigen mencukupi, maka asam laktat akan diksidasi untuk menghasilkan energi melalui metabolisme aerobik. Asam laktat diubah kembali menjadi asam piruvat. Asam piruvat ini masuk ke dalam mitokondria untuk mengalami 
suatu rangkaian proses oksidasi siklus Kreb dan sistem transportasi elekton untuk menghasilkan energi (untuk resintesa $\mathrm{ADP}+\mathrm{Pi}$ ), $\mathrm{H}_{2} \mathrm{O}$, dan $\mathrm{CO}_{2}$.

\section{Daftar Pustaka}

Ahmaidi S. (1996). Effect of Active Recovery on Plasma Lactate and Anaerobik Power Following Repeated Intensive Exercise. Med Sci Sport Exercise.

Astrand P.O. \& Rodahl. K. (1986). Text Book of Work Physiology, second edition. Mc. Graw Hill Company.

Bangsbo, Juel, Hellsten. (1997). Dissociattion Between Lactate and Proton Exchange in Muscle During Intense Exercise in Man. London: Journals Physiology.

Falks B. (1995). Blood Lactate Concentration Following Exercise. International Journals Sport Medicine.

Fox E.L., Bowers R.W. and Fross M.L. (1993). The Physiological Basis of Exercise and Sport. USA: Wim. Brown Publisher.

Harsono. (1996). Manusia dan Latihan. Bandung: ITB.

Janssen Peter (1989) Training Lactate Pulse Rate. Oule Finland, Polar Electro.

Junusul Hairy (1989). Fisiologi Olahraga. Jakarta : Dirjen Dikti.

Mas'ud, Ibnu. (2000). Sinopsis Faal Sistem Pengantar Faal Psikologi. Malang: KOPMA Press. Universitas Brawijaya.

Mattner U. (1988). Lactate in Sports Medicine. Germany: Boehringer Mannheim Gmbh.

Moston, Muska. (1992). Teaching Physical Education. Ohio: Charles E. Meribt Publishing Company.

MEDIKORA Vol.III, No 1, April 2007:61-79 
Nossek Y. (1982). General Theory of Training. Logos : Pan African Press Ltd.

Pate, Rusell R. (1984). Dasar-Dasar Ilmiah Kepelatihan. CBS. College Publishing AS. Térjemahan IKIP Semarang Press (1993).

Soekarman (1987). Dasar Olahraga dan Sistem Energi Predominan pada Olahraga. Jakarta: Komite Olahraga Nasional Indonesia Pusat.

Sugiharto (2003). "Adaptasi Fisiologis Tubuh terhadap Dosis Latihan Fisik". Makalah disajikan dalam pelatihan senam aerobik, Laboratorium Ilmu Keolahragaan, Universitas Negeri Malang.

Weltman A. (1998). Repeated Bouts of Exercise Alter the Blood Lactate RPE Relation. Medical Science Sport Exercise 30 (7). (http://www.lactate.com/pitesbas.hıll) Akses 17 Desember 2007 